\title{
Effective services promotion management in Far North (Russia)
}

\author{
Anna Grabar ${ }^{1, *}$ \\ ${ }^{1}$ Management and marketing department, Vyatka State University, Kirov, Russia
}

\begin{abstract}
The problem of the effective management of services promotion in the Far North (Russia) is topical due to the severe weather and climatic conditions and the high price barrier in this industry. The objective of the article is the analysis of consumer market characteristics and the formation of specific recommendations on services promotion for the industries. Statistical methods and methods of analysis, synthesis, decomposition and expert assessments used in the study revealed the features of the consumer market. The article highlights the factors and patterns of communication services market functioning and its development dynamics. Specific recommendations on the actions in competitive market are given to the companies providing communications services.
\end{abstract}

\section{Introduction}

Unlike other industries: metallurgy, mechanical engineering, mineral extraction, energy, where the main facilities were built in Soviet times, the telecommunications sector has arranged from scratch in new Russia. For this reason, on one hand, our country is experiencing lag from the most economically developed countries in the sphere of information and telecommunications; on the other hand, there is no need to support and maintain outdated technologies in the industry.

One of the priorities of the Innovation Development Strategy of the Russian Federation for the period until 2020 is the formation of modern information and telecommunication infrastructure, ensuring a high level of its accessibility, and provision of high quality services on its basis [1].

Objective of the study was to explore consumer factors that affect the development of the provisions of the strategy to promote services of telecommunication companies.

\section{Methodological framework}

To achieve the goal the following tasks were set: to give a general description of the behavior of mobile users in the region, to identify factors affecting the penetration of mobile Internet, to reveal consumers' satisfaction level and positive attitude to cellular communication companies, represented in the region, and to identify channels of information used by consumers and which are particularly trusted.

The object of the research is a set of users of communication services among Yamal-Nenets Autonomous District urban residents.
Research method: results study of various market research reports, sampling results and the formation of a common understanding of the state of telecommunications services in the regions of the far north. The analytical study database includes the works of these authors [4-22], who in their studies considered various market aspects of the Yamalo-Nenets Autonomous District

\section{Results}

\subsection{The number of subscribers who use the services of the mobile operator is defined}

Thus, it was found that $64 \%$ use one provider, while $36 \%$ use several providers, which indicates that the vast majority use one operator, however, the number of subscribers seeking to maximize the benefit from using services of several companies can increase. [10]

As a rule, subscribers who need to optimize the cost of long-distance and international communication services use several operating companies. Thus, $16 \%$ of subscribers for long-distance and international communication services use the minor operator [10].

Only $4 \%$ of respondents believe that competing companies offer better mobile Internet

\subsection{Customer loyalty is estimated}

According to limitation period of connection to the main telecom operator it was found that $66 \%$ of respondents use services more than 5 years, $19 \%$ - from three to five years, $12 \%$ - from one to three years, $3 \%$ - less than a year. This demonstrates the preference of consumers to choose operators sensibly and have long-term relationships with them. [7] 


\subsection{The main factors of operator choice}

Among the most important factors in the choice of mobile operator the interviewed emphasize:

- optimum by price tariff considering traffic and discount $-85 \%$;

- quality of services and communication - 75\%;

- low prices - 72\%;

- high quality of innovative and additional services $40 \%$;

- reliability and reputation of the operator - 38\%;

- image - 14\%;

- recommendations of friends and acquaintances $11 \%$. [8]

Evaluation of the factors shows that subscribers' demand to telecommunication companies at the moment is to create optimal tariffs (or tariff package) for different users, providing quality of services, fair prices and innovation.

\subsection{Impact of substitute products on the market}

About 20\% use the services of IP-telephony (Skype, GoogleVoice, etc.), while $80 \%$ of respondents do not use them. A total of $15 \%$ use special applications instead of SMS, and $85 \%$ - do not use them; it is not common among subscribers to use substitute services of cellular communication [5].

\subsection{Prospects for promotion of mobile Internet services on the market}

A positive aspect in the mobile communication segment is that in the test group the number of smartphones (71\%) exceeded the number of regular phones (29\%), which contributes to the implementation of forwardlooking strategies of the company in the mobile segment [6].

\subsection{Channels for disseminating information on the market}

Mass communication plays an important role in the dissemination of information on new services and opportunities of companies, with official website, a means of self-initiation of consumer communication, being the most convenient and informative according to customers $(41 \%)$. In the presence of home Internet access, $79 \%$ of the respondents consider online advertising as the most promising means of information. Also, consumers trust the recommendations of friends and acquaintances (39\%), TV advertising (29.6\%), consult with specialists from company office or contact center $(28.8 \%)$, see outdoor advertising, read printed leaflets, brochures (26 with the official website recognized as the most convenient and informative by consumers $(41 \%), \%)$ and listen to advertising on radio $(17 \%)$ [12].

The high rate of the recommendations of friends and acquaintances $(39 \%)$ demonstrates an important role of accounting gain of horizontal linkages in society for marketing communications. Frequent use of social networks and blogs in Russia also confirms the horizontal linkages gain - with the help of mobile Internet $83 \%$ of respondents visit these resources. At sufficiently high rate of obtaining information through TV advertising (29\%), it was possible to understand consumers' attitude to regional TV advertising:

- $34 \%$ of respondents do not watch TV, they watch videos on the Internet;

- $31 \%$ easily watch TV with turned-on sound and

have their favorite video clips;

- $29 \%$ try not to watch ads and immediately switch the channel

- $5 \%$ turn the sound off.

One can say that TV advertising has a communications capacity in the regional market. Out of $31 \%$ of those who watch commercials easily, $29 \%$ acquire some information. However, $68 \%$ somehow try to avoid advertising, which under high advertising charge can make it economically inefficient [3].

The importance of interactive and personalized communications in relation to the company and the subscriber is confirmed by consumer behavior in the field of tariff plan change or the connection of a new service. For this respondents usually choose: consultation with a specialist from the office or contact center $-56 \%$, company's official website $-33 \%$, the system of self-service activation / deactivation $-31 \%$ [14].

\subsection{Regional consumption of additional mobile services, emphasizing the services of the mobile Internet}

The popularity and revenue from SMS and MMS services sale decreases, but in the segment of additional services they still occupy leading positions $-79 \%$. The second most popular additional service is the mobile Internet [9].

Today, the segment mobile data transmission has become one of the fastest growing segments of the additional services in cellular networks in Russia. The basis of the active growth of this segment is actively deploying the third and fourth generation networks, increase of smartphones and tablets' user audience and traffic consumed by users (Fig.1)

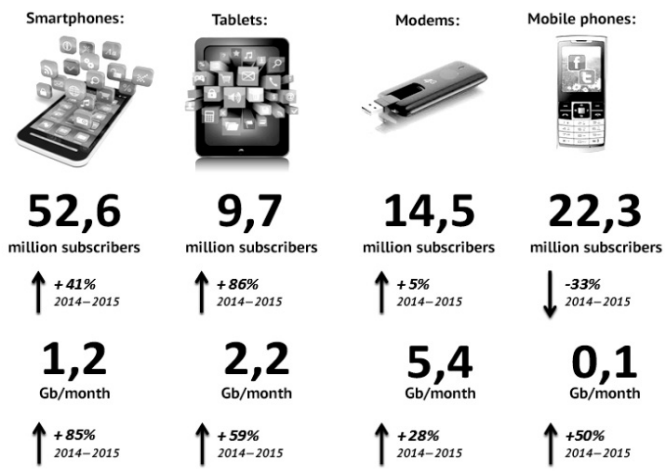

Fig. 1. The number of active subscribers and average traffic of mobile Internet per active user per month in Russia in 2014[19]. 
From the analysis of the activity of the mobile Internet service use, depending on the age of the subscriber, it is obvious that the service is especially in demand among young people aged 18-24 years, i.e. the student's age. The penetration rate reached more than 55\%. In the age group of young people from 25 to 35 , the level reduced to $45 \%$, which is also high. For consumers between the ages of 16-17 years, that is, the level of high school students, it was 30\%. And for respondents aged 36-55 years, the level of mobile Internet penetration reached $40 \%$.

According to the survey, subscribers often use mobile Internet in places of recreation and leisure activities $76 \%$, in transport $-66 \%$, at work - $63 \%$, at home $-54 \%$. With the help of mobile internet, $83 \%$ of respondents visit social networks or blogs, $72 \%$ visit various websites, 66\% check emails, 54\% download music and books, $30 \%$ download/watch videos, $28 \%$ use geolocation services, $14 \%$ pay for goods and services via the Internet. [10]

On the regional market mobile Internet is developing and being used quite actively. In the next 12 months respondents: think they will spend more time on-line $17 \%$, think they will spend the same amount of time $65 \%$, think they will spend less time $-10 \%$, will not use mobile Internet at all $-8 \%$. The perspective of mobile Internet market development is obvious [16].

However, the barriers to the mass distribution of «Mobile Internet» service in the region, according to respondents, are: poor quality of networks, lack of «high speed internet» $(56 \%)$, too high price for mobile data transmission traffic $(55 \%)$, high cost of smartphones and tablets (25\%), no need for mobile Internet (13\%) [17].

At present, with the package offer of cellular service subscribers spend on mobile communication on the average per month: up to 200 rubles $-22 \%$ of respondents, 201-499 rubles - 45\%, 500-999 rubles $24 \%$, more than 1000 rubles $-8 \%$. At that, $26 \%$ of those who spend up to 200 rubles and $34 \%$ of those who spend up to 499 rubles are ready to increase spending on cellular services, provided unlimited mobile internet and introduction of a variety of additional services; however, $57 \%$ of this group are strictly not willing to increase their spending; of those who spend no more than 999 rubles $26 \%$ are ready, and of those who spend more than 1000 rubles $13 \%$ are ready. [14]

In general, the subscribers are ready for services based on new technologies and some of active mobile Internet users are willing to spend more on mobile communications.

\subsection{Market monopolization level assessment}

There are five operators on the communication market of the Yamalo-Nenets Autonomous District:

- Rostelecom;

- telecommunication group MOTIV;

- MegaFon;

- MTS;

- VimpelCom (Beeline).
$62 \%$ of respondents consider Rostelecom as their primary provider, 14\% - Motive, 9\% - Megafon and MTS, $6 \%$ - Beeline. It is obvious that Rostelecom is the absolute leader of the largest subscriber base in the market [20].

In the process of comparing their major operator with competitors, respondents noted that their operator is: much better ( $22 \%$ of respondents), better in some ways (37\%), approximately the same (22\%) [10].

According to the study results it can be concluded that the regional market of basic telecommunication services is mature. It is also obvious that the services based on mobile Internet are in demand among the population of working age, especially among young active audience.

For the improvement of strategies to promote telecommunication services on this regional market is necessary to carry out its segmentation to determine the market structure and define the guidelines for strategic actions.

To determine the formation conditions of services promotion strategy, it is also necessary to take into account the main characteristics and problems of the region's population.

\subsection{Study of the regional market features}

The Russian Federation is quite a unique country, which has a large share of polar and subpolar areas with a harsh climate. They are referred to as the «regions of the Far North and equated localities» (Fig. 2). Out of 17,1 million $\mathrm{km} 2$ of Russian territory, 11 million $\mathrm{km} 2$ or $2 / 3$ of its area is the territory of the Russian North, which is home to 10039065 people or $6,99 \%$ of Russian population [13].

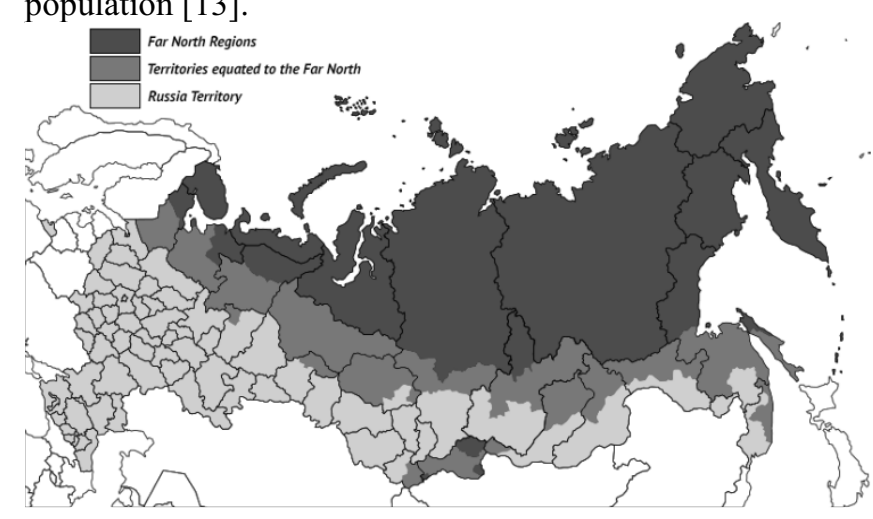

Fig. 2. Regions of the Far North and equated localities.

In general, according to the approach adopted in the Russian Federation, the Far North and equated localities can be characterized by a number of common features from the economic and natural points of view. They include unfavorable climate, permafrost, long distances from the main economic and cultural centers, high transport costs, rise in price of construction and production, high cost of living, and environmental vulnerability of the territory [11].

Because of the severe climatic conditions communications networks service of the Far North is significantly hampered. However, low density of population and its geographical dispersion makes 
telecommunications services consumers more susceptible to the development of new services, such as broadband access, video conferencing, intelligent network, etc. [13-18].

According to the official statistics website, the total population of the Yamal-Nenets Autonomous District in 2014 amounted to 539,7 thousand people. The share of urban population is $83.1 \%$ [13].

Yamalo-Nenets Autonomous District has significant economic value, the basis of the autonomous region's economy is oil and gas extraction. According to the rating of Russian regions in living standards, YamaloNenets Autonomous District is the 45th among 83 subjects of the Russian Federation, but it is the 2nd after Moscow by the level of per capita income and the 6th by the level of economic development [23].

In the ranking of life quality Yamalo-Nenets Autonomous District has maintained the negative trend for the past two years: in 2014 it has lost positions in the eight groups of ten. Despite the fact that the subject of the Russian Federation is among the top ten in socioeconomic conditions rating of Russian subjects on the results of 2013 according to the RIA Rating Agency [22], it affects the quality of people's life less than one would expect: this significant advantage nullifies a lot of drawbacks, including poor territory development, severe weather conditions, insufficient small business development, poor housing conditions quality [22].

\section{Discussion}

One of the traditional problems of the telecommunication market companies in the northern regions is shortage of main canals, which leads to the fact that operators construct optical lines in those areas where population density is more or less acceptable. In most areas the focus is on the use of satellite communication channels, through which most of the traffic is transferred.

The demand for mobile services is growing both among businessmen and among people. Given the rapid turnover of information technology, it is not effective for companies operating in the mobile market, only to sale services or to lease communication channels. Therefore, the percentage of their participation in information and services provision increases every year.

Transport infrastructure communication development, active promotion of broadband Internet access and other innovations are the basis of effective implementation of a business model of any telecommunication company in the Russian market. Thus, of communication services development is one of the most competitive areas of the Russian Far North economy.

The main regularities of communication services spread in the Far North area has developed as a result of historical, cultural and natural development of the region. For the Russian North regions with their vast territories, low population density, and unequal living conditions, the formation of the telecommunications market through the telecommunication and information infrastructure development is of particular importance and it has its competitive features. For example, the short northern summer is the time of construction and repair work, related to communication networks laying, base stations installation and their adjustment and other works. At the same time, summer is the traditional vacation period, and most residents spend it in the south of our country or in foreign countries. During this period, amounting, as a rule, to two-month period, subscribers' activity drops significantly.

It is possible to make recommendations on improving the promotion of communication services, to find and justify solutions to the identified problems through strategic actions in the field of services promotion (Table 1).

Table 1. Problems of communication sector and recommendations for their solution.

\begin{tabular}{|c|c|}
\hline Problem & $\begin{array}{l}\text { Directions strategic decisions in } \\
\text { promotion field }\end{array}$ \\
\hline $\begin{array}{l}\text { The impossibility of } \\
\text { further extensive } \\
\text { development of basic } \\
\text { services as a result of } \\
\text { market saturation }\end{array}$ & $\begin{array}{l}\text { Maintenance of a high degree of } \\
\text { customer loyalty and satisfaction } \\
\text { of existing customers needs in } \\
\text { order to save customer bases, } \\
\text { strengthening of relations. } \\
\text { Attracting of newly appearing } \\
\text { customers, dissatisfied with } \\
\text { competitors customer services }\end{array}$ \\
\hline $\begin{array}{l}\text { The highest growth } \\
\text { rates of consumption } \\
\text { and the amount of } \\
\text { revenue from Mobile } \\
\text { Internet service in } \\
\text { the central regions, } \\
\text { low innovation } \\
\text { value, low solvency } \\
\text { of the population }\end{array}$ & $\begin{array}{l}\text { Learning of preferences and } \\
\text { living conditions of regional } \\
\text { consumers, development of } \\
\text { relevant special methods of } \\
\text { services promotion, together with } \\
\text { the stimulation of change of } \\
\text { mobile phones to smartphones } \\
\text { and tablets, supporting } \\
\text { technologies to provide additional } \\
\text { services to create potential } \\
\text { customers. Information and } \\
\text { conclusiveness of advantages and } \\
\text { additional mobile Internet } \\
\text { opportunities, promotion of high- } \\
\text { traffic use of additional services }\end{array}$ \\
\hline $\begin{array}{l}\text { The high cost of } \\
\text { traditional } \\
\text { advertising to reduce } \\
\text { its effectiveness }\end{array}$ & $\begin{array}{l}\text { To seek the optimum set of } \\
\text { marketing mix in the } \\
\text { individualization of demand } \\
\text { conditions, with an emphasis on } \\
\text { personalized interactive } \\
\text { marketing communications tools, } \\
\text { which will reduce costs and } \\
\text { increase communication } \\
\text { effectiveness by targeting, } \\
\text { consumer interest to information, } \\
\text { and absence of negative attitude } \\
\text { of consumers. To promote the } \\
\text { popularity of self-services and } \\
\text { contact centers }\end{array}$ \\
\hline $\begin{array}{l}\text { With the } \\
\text { development of } 4 \mathrm{G} \\
\text { technologies, new } \\
\text { communications } \\
\text { services imminent } \\
\text { appearance on the } \\
\text { market is possible } \\
\text { from third-party } \\
\text { communications } \\
\text { companies (OTT) }\end{array}$ & $\begin{array}{l}\text { Formation of long-term } \\
\text { relationship of trust with } \\
\text { consumers and a positive attitude } \\
\text { to the company brand, continuous } \\
\text { techniques improvement. } \\
\text { Creation of special cooperation } \\
\text { terms with the aim of non- } \\
\text { appearance of the need for new } \\
\text { types of communication or } \\
\text { competitors services }\end{array}$ \\
\hline
\end{tabular}


Thus, as a result of the work, the authors found general problems, which are faced by telecommunication companies, working in the Far North at the present stage of telecom market development and formulated basic recommendations.

Also it is necessary to highlight key communication tasks of services promotion strategy:

- development of high loyalty level, strengthening of relationships with consumers, attraction of unsatisfied customers of other companies and making loyal customers of them;

- specialized approaches to promotion of new services on the regional markets, increasing the level of customer involvement in telecommunication companies products, as well as the involvement of consumers in the brand.

\section{Concluding remarks}

As a result of the work, the authors found general problems, which are faced by telecommunication companies, working in the Far North at the present stage of telecom market development and formulated basic recommendations.

1) Building long-term relationships between the company and the consumer in the telecom market is both the factor of company stability in the market and success of the market and competition of its development. Marketing communications of most operators are still based on the traditional approach and on standardization of technologies. However, the consumer behavior model has undergone profound changes in recent years.

2) To achieve long-term cooperation between the company and the consumer on mutually beneficial conditions customers should be considered as heterogeneous audience of different groups of loyalty. In this respect, companies' communication actions should simultaneously adjust risk groups and retain stable group of consumers.

3) According to traditional approaches, the essence of promoting is in the complex of measures aimed at demand formation and sales stimulation, i.e., in the end, to sales increase. Also promoting is interpreted as the concept of marketing communications, which refers to bonds formed by the company with contact audiences through a variety of influence means, including advertising, PR, sales promotion, promotion, personal selling, as well as informal sources of information e.g. rumors and gossip.

4) Specific features of the cellular market in the Far North are found. Among them are: preferential use of satellite communication channels due to natural and climatic peculiarities; subscriber base limitation due to the low population density in the region; dependence of need for mobile communication services on the level of socio-economic development of inhabited locality; available natural resources and the economic feasibility of their development, influencing the structure and volume of information services consumption.

\section{References}

1. Russian Federation Government Resolution of 15.04.2014 no. 313 "On approval of the Russian Federation "Information Society state program (2011-2020)".

2. Marketing research of Russian market of telecommunication systems (2014). http://marketing.rbc.ru/download/research/demofile _562949992562127

3. The concept of long-term Russia's social and economic development until 2020.

4. Y.A. Kuznetsov, S.E. Markova, Structural approach. Nizhny Novgorod State Technical University, 3 (2013)

5. The future of the telecom market belongs to services. http://www.iksmedia.ru/news/5021990-Budushheetelekomrynka-za-servisami.html

6. IKS-consulting summarized the development of the telecommunications market and gave the forecast for 2014-2018. http://www.contentreview.com/articles/25920/

7. The main trend of telecom is profitability stagnation. http://www.cnews.ru/reviews/new/telekom_2014/art icles/glavnyj_trend_telekoma_stagnatsiya_rentabel nosti/

8. Telecom 2015: the icy serpentine road. Available at: http://www.mskit.ru/news/n176857/

9. The review and assessment of development prospects of world and Russian markets of information technologies. http://fs.moex.com/files/9216 (2014)

10. N.M. Rozanova, D.A. Bulichenko, Terra Econ, 9 (2011)

11. E.M. Grishanova, E.A. Krasnoslobodtseva, TCommm, 7 (2014)

12. Regulation of the telecommunications industry in Russia: trends and perspectives (2015). http://json.tv/ict_telecom_analytics_view/regulirova nie-v-telekommunikatsionnoy-otrasli-rossiitendentsii-i-perspektivy-20150305052453

13. The economic and social indicators of the Far North and equated localities in 2000-2013 (2014) http://www.gks.ru/bgd/regl/b14_22/Main.htm

14. V.A. Vityazeva, E.S. Kotyrlo, Syktyvkar State University publ. (2007)

15. A.A. Sozinova, Analytical and methodological support of regional development projects. In the World of Scientific Discoveries, 11 (2013)

16. V.V. Fauzer, G.N. Fauzer, I.G. Nazarova, G.V. Korshunov, Trends and prospects of socio-economic development of the northern regions of Russia: demography, labor, migration, resettlement (EkonInform publ., Moscow, 2012)

17. The analysis of the Russian market of additional mobile services (VAS), Advanced Communications \& Media (2008). http://www.acm- 
consulting.com/data-downloads/doc_download/26vas-forum-presentation.html

18. A. Rachinsky, The spread of mobile communication in Russia. Litres (2014)

19. The development of mobile Internet access in Russia and worldwide: Preliminary results of 2014 (2015). http://json.tv/ict_telecom_analytics_view/razvitiemobilnogo-dostupa-v-internet-v-rossii-i-mirepredvaritelnye-itogi-2014-goda-20150317043818

20. A.V. Kalinin, Economics publ., 3 (2014)
21. CNews Telecom 2014: The largest telecommunications company in Russia. http://www.cnews.ru/reviews/new/telekom_2014/

22. A.A. Kobylko, Virtual operators as a system resource of the telecommunications market in Russia (Moscow, CEMI RAS publ., 2012)

23. Ranking of the Russian regions on life quality. Moscow, (2014). http://vid1.rian.ru/ig/ratings/life_2014.pdf

24. Ranking of socio-economic situation of the Russian Federation. Results of 2013, (2014). http://vid1.rian.ru/ig/ratings/rating_regions_2014.pdf 